\title{
DIDAKTIČKO METODIČKI PRISTUP RAZVITKU EKOLOŠKE SVIJESTI DJECE U PRIPREMNOM PREDŠKOLSKOM KURIKULU
}

\author{
Vlasta Lipovac, Marija D. Sakač, Aleksandar Janković i Jelena Raičević
}

Visoka škola strukovnih studija za obrazovanje odgajatelja

Ćirila i Metodija 18, 37000 Kruševac, Srbija e-mail: vlastasucevic@gmail.com

\begin{abstract}
Sažetak
Osobit je izazov i zadatak svih onih čiji je poziv odgojno-obrazovni rad, prije svega, razvitak institucijskog obrazovno-odgojnog sustava, a onda i svakidašnje pedagoške prakse. Nužno je koncipirati i kurikule koji bi trebali biti u funkciji potpore suvremenim tendencijama kako u odgoju i obrazovanju uopće, tako i na planu razvitka ekološke svijesti i poželjnog stila života mladeži. Zbog toga je, obzirom na već postojeći institucijski predškolski odgoj i obrazovanje, od osobite važnosti situirati u kurikulu na odgovarajuci način i pitanje tzv. ekoloških sadržaja, kako bi se u ovoj, za odgoj, najosjetljivijoj dobi, mogao provesti što učinkovitiji utjecaj na razvoj ekološke svijesti kod djece $i$ ljubavi prema prirodi. U skladu s navedenim, u ovom su članku najprije razmotrene bitnije značajke i tijek spoznajnog razvoja djece predškolske dobi. Zatim smo sagledali najprihvatljivije sadržajne, strategijske $i$ didaktičko-metodičke odrednice koje bi trebale obavezno odlikovati funkcionalno pribvatljiv kurikul u segmentu suvremeno utemeljenog ekološkog odgoja i obrazovanja djece predškolske dobi. Osim predloženog nacrta najprihvatljivijih kurikularnih sadržaja, odgajateljima-praktičarima upućeno je i niz konkretnih prijedloga didaktičko-metodičke naravi. Najviše zbog potrebe praktične realizacije sadržaja kurikula ekološkog odgoja i obrazovanja pretežito u vezi s iskustvenim aktivnostima djece u njihovom realnom životnom okružju, a koje bi se posebice odnosile na: izravna promatranja $i$ doživljaje; mislenu preradu izravno ili neizravno percipiranih i doživljajnih pojava.
\end{abstract}

Ključne riječi: ekološki odgoj, kurikul, predškolsko dijete, spoznajni razvitak

\section{UVOD}

U cilju razvitka održivog društva i održive ljudske zajednice, djecu u prvim godinama života treba pripremati za aktivne članove održivog društva, za što je, kako navodi Cifrić (2012) nužno i permanentno održivo preoblikovanje. Tim više što ranu dob odlikuje nagli razvoja socijalnih i emocionalnih kapaciteta koji trebaju pripremiti i osposobiti djecu u smjeru samouvjerenosti, povjerljivosti, empatije, intelektualne radoznalosti, sposobnosti ovladavanja jezikom i drugim komunikacijskim vještinama. To, konkretno, znači očekivanje razvoja sljedećih sposobnosti kod djece: 
- iskustvo, upravljanje i očitovanje cijelog spektra pozitivnih i negativnih emocija;

- razvitak bliskih i zadovoljavajućih odnosa s drugom djecom i odraslima;

- aktivno istraživanje svojeg okoliša i učenje (Cohen i sur., 2005).

Zainteresiranost za životnu okolinu javlja se vrlo rano, od trenutka kad dijete počne upoznavati, proučavati i shvaćati svijet oko sebe. Tijekom ranog iskustvenog razdoblja dijete prve spoznaje o svojemu životnom okružju dobiva od roditelja, a zatim i kroz predškolski odgoj i obrazovanje (Sakač i sur., 2012; Janković, 2015). U rješavanje ekoloških problema s kojima se sučeljava današnji čovjek nužno je uključiti i djecu. Odgoj i obrazovanje u ranoj dobi imaju neprocjenljivu ulogu za razvitak globalnog stanovništva (Johansson, 2009) i održive zajednice (Cifrić, 2012).

Održivu zajednicu odlikuje više gledišta: osjećaj građanske dužnosti, politička jednakost, solidarnost, povjerenje i tolerancija (Cifrić, 2012). Zato su, od osobite važnosti ekološke spoznaje stečene u inicijalnom obrazovanju djeteta. S obzirom da kritično (osjetilno) razdoblje, u kojemu se dijete predškolske dobi nalazi, osigurava najučinkovitije učenje, poželjno je da svaki odgajatelj u cilju razvoja ekološke svijesti i ekološkog stila života djece, uvodi i primjenjuje ekološke programe utemeljene na vrijednostima održive zajednice.

Odgojno-obrazovni proces na predškolskoj razini je specifičan, a održivi razvoj i ekološki odgoj, također, po svojoj biti odlikuje specifičnost. Zato je nužno ove pojmove dovesti u jedan suvisli sustav, koji se temelji na univerzalnim vrijednostima, kao što su ljubav prema životu, zajednici, pozorni odnos prema drugim živim bićima uz uvažavanje njihovih potreba, a što uključuje, humanost, altruizam, empatiju, solidarnost, toleranciju, jednakost i sl. Ekološki orijentirani programi utječu na oblikovanje ekoloških stilova kod djece. Zato ekološka problematika zauzima bitno mjesto u predškolskom kurikulu. Brojni autori se slažu da djeci na primjeren način treba približiti sustav znanja iz područja održivog razvoja, poštivajući načelo postupnosti. „Proces ekološkog senzibiliziranja ljudi mora biti stalan i dugoročan, mora se odvijati na svim razinama (globalnim i lokalnim) i obuhvaćati organiziranje specifičnih institucija, ustanova i ustrojstava koji će pridonositi razvitku ekološki utemeljenih normi i zakona, kao i razvitku ekološke svijesti i kulture. Dio tih napora obvezna su preuzeti brojna ustrojstva i ustanove neformalnog i formalnog sustava obrazovanja i odgoja, s ciljem razvitka etike osobne odgovornosti prema prirodi i okolišu u kojemu živi i radi, kod svakog pojedinca" (Klemenović, 2009:7). Na taj način, djeca od najranije dobi imaju mogućnost obrazovati se za održivi razvitak. Od njih se očekuje razvoj sposobnosti i kompetencija značajnih za sučeljavanje i rješavanje ozbiljnih ekoloških problema.

Djeca imaju pravo na edukaciju od strane pojedinaca i institucija, od kojih se očekuje da stvore učinkovite kontekste za učenje o premisama za održivost (Hägglund i Pramling Samuelsson, 2009). Suvremeni oblici ustrojstva odgojno-obrazovnog procesa u središte programskih sadržaja uključuju ekološku edukaciju kao vid usvajanja određenih znanja, oblika ponašanja i oblikovanja poželjnih svojstava osobnosti značajnih za očuvanje i zaštitu životnog okoliša (Sakač i sur., 2012). 
U suvremenim uvjetima odgoja i obrazovanja, kurikul postaje jedno od najvažnijih sredstava za osiguranje kvalitetnog i ravnopravnog obrazovanja za sve, tvoreći, ne samo odraz danog društva i kulture, nego i projekciju budućeg izgleda tog društva (Sučević i sur., 2013; Ellis, 2004), prema orijentaciji, svrstava kurikule u tri temeljne skupine: kurikul usmjeren na dijete, kurikul usmjeren na društvo i kurikul usmjeren na znanje. U okviru kurikula usmjerenih na dijete, osobito mjesto zauzimaju tzv. „zeleni kurikuli“. „Ozelenjavanje“ kurikula podrazumijeva stvaranje prilika za razvitak svih sudionika odgojno-obrazovnog procesa koji, slijedeći autentičnu motivaciju za učenje, proširuju smisao sentencija „biti globalni građanin“ i „biti ekološki odgovoran čovjek“. Cilj „ozelenjenog" kurikula je razvitak ekološke svijesti (ekoloških znanja, stavova, vrijednosti i ekološkog ponašanja) i ekološko opismenjavanje djece kroz „zelene“ aktivnosti i sadržaje (Klemenović i Marić Jurišin, 2012). U tom se smjeru realiziraju brojne nacionalne strategije ekoloških aktivnosti i ekoloških sadržaja za djecu predškolske dobi koji poprimaju globalne razmjere. Poznato je da je indonezijska „Zelena škola“ proglašena za najzeleniju školu svijeta u 2012. godini. U okviru škole postoji i vrtić koji radi po posebnom zelenom kurikulu za djecu rane i predškolske dobi (Curriculum: Early Years Program: Pre-K and Kindergarten).

\section{EKOLOŠKA EDUKACIJA KAO UVJET ODRŽIVOG RAZVITKA I OPSTANKA}

U sferi utjecaja životnog okoliša na dijete i njegovog utjecaja na okoliš, Bronfenbrener (1997) naglašava njegov transakcijski karakter. On ističe tri razine djelovanja ekosustava okoliša na dijete (čovjeka). Prvi i najsnažniji utjecaji dolaze iz djetetovog mikrosustava koji je najbliži djetetu (obitelj, vrtić, škola, vršnjaci, crkva...). Veza između više mikrosustava pripada mezosustavu. Sljedeći utjecaj dolazi od egzosustava i očituje se na neizravan način. Najširi eko sustav je makro sustav i njegovi utjecaji su, također, neizravni.

Glede toga da predškolska dob omogućuje najučinkovitije usvajanje znanja, poželjno je da svaki odgajatelj u cilju razvoja ekološke svijesti kod djece provodi svoj utjecaj preko ekoloških programa utemeljenih na vrijednostima održive zajednice. Odgajatelj treba biti u trend s ekološkim događajima i sam ekološki obučen, odnosno imati ekološke kompetencije, kako bi u svojemu radu odgovorio na aktualne ekološke probleme i izazove.

Osobita privilegija odgajatelja očituje se u njegovoj mogućnosti utjecanja na oblikovanje i razvoj svijesti kod djece, kada su ona najprijemljivija za odgoj i učenje i kada je oblikovanje socijalno-emocionalnog razvoja najlakše. Mogućnost razvoja i njegovanje ljubavi prema prirodi i oblikovanje punog doživljaja prema njoj te humanističkim vrijednostima vrlo je velika u predškolskoj dobi. Posebice su značajna ekološka saznanja stečena u inicijalnom obrazovanju djeteta. Ekološka pismenost i vrijednosti održive zajednice imaju osobito značenje i u daljnjem razvitku ekološke svijesti i ekoloških spoznaja. Ekološki orijentirani programi utječu i na oblikovanje ekoloških stilova kod djece. 
Odgajatelj svojom kompetencijom i humanističkom orijentacijom, kao i razvijenom osjetljivošću za potrebe djeteta, umnogome utječe na razvojne kompetencije djeteta (Sakač i sur., 2012). Ugodna i poticajna atmosfera u vrtiću i njegovom okolišu, koja uključuje aktivni boravak djece u prirodi, s mogućnostima participacije u uređenju vrtića, dvorišta i okoline, razvija osjećaj korisnosti, zajedništva i ljepote. To pruža priliku za razvoj životnog stila i utemeljenje životne filozofije djeteta. U radu odgajatelja s djecom diferenciraju se mnoge tendencije i zainteresiranost za životni okoliš i ljubav prema prirodi, što će se odraziti na ekološku kulturu i ekološku svijest djeteta. Na taj način, odgajatelj razvija dodatnu motivacija za svoj rad i postaje uspješan organizator i kreator rada, kao i nositelj uspješnog ekološkog programa. Sposobnost odgajatelja u iniciranju dobre komunikacije i kooperacije $s$ ostalim osobama koje imaju svoj upliv u dječjem razvoju i odgoju, kao i među djecom međusobno, vrlo je značajna glede oblikovanja ekološke svijesti u djece. Isto tako, pravilan odabir sadržaja prilagođenih uzrasnim i kognitivnim sposobnostima, kao i ostalim značajkama i potrebama djeteta, treba probuditi zainteresiranost za životni prostor, prirodu i boravak u njoj, a što je, po mišljenju najvećeg broja psihologa i pedagoga, bit i kognitivističke orijentacije, najbolja prilika za dijete da nešto, što izravno opaža i doživljava, to i na najbolji način usvoji i najpotpunije razumije (Janković, 2016:23-26). Sukladno tomu, odnosno izravnom kontaktu djeteta s prirodom, pozitivno se utječe i na mentalno zdravlje te jača njegova potreba $\mathrm{z}$ suživotom s prirodom. Boraveći u prirodi, dijete upoznaje fizičku okolinu, zadovoljava svoju radoznalost i potrebu za kretanjem, očituje svoju pozitivnu emocionalnost i dobro raspoloženje (Sakač i sur., 2013). Međutim, same ekološke aktivnosti nisu dostatne, nužni su dobri ekološki programi, odnosno kurikuli.

Kompetentnost odgajatelja u osmišljavanju dobrog ekološkog programa predmnijeva njegova metodička i psihološka saznanja. Zato treba znati, da su za oblikovanje uspješnog predškolskog kurikula osobito značajna tri epistemološka polazišta: Piagetova teorija kognitivnog razvitka, Teorija kulturno-povijesnog razvitka Vygotskog i Gardnerova teorija multiplih inteligencija. Sukladno tomu, značajan je i analitički pristup (Lepičnik-Vodopivec, 2000) dječjem ekološkom razvoju u okviru biheviorističke, psihoanalitičke, kognitivističke, humanističke i ekološke orijentacije.

Bihevioristički pristup, u razvoju osjetljivosti prema životnoj okolini, ističe ulogu reakcija djeteta na podražaje iz njegove okoline. Psihoanalitička teorija naglašava djetinjstvo kao najznačajniji razvojni stadij u životu čovjeka za sve procese učenja, što znači i za učenje o životnoj okolini. U kognitivističkom pristupu zona narednog razvoja je primarna, ali i utjecaj genetskih predispozicija u zajedničkom djelovanju s čimbenicima sredine koji oblikuju dječje mišljenje, uključujući i ekološko. Humanistička orijentacija temelji se na poticanju razvoja samosvijesti i psihičkog zdravlja. Sukladno tomu, humanistički pristup obilježava jedinstvenost čovjeka i svijeta. Ekološki odgoj temelji se na ideji, kako navodi Veresov (2002), da se sustav koji tvori čovjek i njegova okolina ne sastoji od subjekata i objekata, već od njihovih relacija i odnosa. Ekološki pristup uključuje utjecaje obitelji, predškolske ustanove, odgajatelja, vršnjaka, vidljivog i prikrivenog kurikula, kao i stavova roditelja i lokalne zajednice prema problemima ekološkog odgoja. 


\section{PEDAGOŠKO-PSIHOLOŠKI PRISTUP PROBLEMU EKOLOŠKOG ODGOJA I OBRAZOVANJA DJECE PREDŠKOLSKE DOBI}

Osim poznavanja i uvažavanja specifičnosti dječjeg spoznajnog razvoja, za uspješan odgojno-obrazovni rad u dječjem vrtiću na razvijanju ekološke svijesti i pojmova u vezi s prirodom i ekološkom edukacijom, potrebno je poznavati određene specifičnosti učenja predškolskog djeteta. Kamenov (1999), među inim, učenje predškolskog djeteta definira kao proces prerade i uobličavanja iskustva, uviđanja, otkrivanja, shvaćanja biti pojava, rekonstruiranje već postojećih znanja i uspostavljanje asocijacija među znanjima. U širem smislu to je stjecanje osobnog - osjetilnog, motoričkog i simboličkog iskustva o društveno povijesnom iskustvu svijeta. S druge strane, Marendić (2009) ističe da u procesu učenja u predškolskoj dobi dominira učenje potpomognuto osjetilnim i motoričkim iskustvom koje prethodi simboličkom učenju na višim razinama i služi mu kao polazna osnovica. Učenje djece predškolske dobi zahtjeva potpunu praktičnu i mislenu aktivnost djeteta, što se postavlja kao temeljni uvjet i u oblikovanju početnih pojmova o ekologiji. Iz ovoga proizlazi i temeljna značajka učenja predškolskog djeteta, a to je pounutrašnjivanje praktičnih radnji na unutarnji misleni plan.

Navedena su saznanja o kognitivnom razvitku djece i značajkama učenja povezana $s$ konstruktivističkom paradigmom i konstruktivističkim načinom učenja djece. Bit je konstruktivističkog pristupa učenju u interakciji djeteta s materijalima, idejama i ljudima. Temeljna je ideja konstruktivističkog učenja konstruirati novo znanje temeljem prethodnog, što je u cijelosti suprotno gledištu u kojemu je učenje pasivno prenošenje informacija. Konstruktivistički teorijski pristup ističe izgradnju znanja i razumijevanja svijeta temeljem vlastitog iskustva i prethodnog znanja, što tvori jedinstvo procesa učenja za svakog pojedinca. Svako novo znanje i iskustvo djeteta temelji se na prethodnom znanju i čini konstruktivni element novih spoznajnih struktura. Naglasak je na stjecanju znanja iz prve ruke, na aktivnoj ulozi subjekta u građenju svojega znanja i razumijevanja stvarnosti: „Konstruktivizam je znanstveno-teorijski koncept koji pruža važne argumente za prosudbu različitih znanstvenih koncepcija. $\mathrm{O}$ primjerenosti teorije ponašanja, teorije aktivnosti i teorije sustava, tako glasi zaključak, ne može se odlučivati pozivanjem na zbilju. Pri tom je riječ o ljudskim konstrukcijama koje su nastale u kontekstu konkretnih sklopova aktivnosti te se unutar njih trebaju i prosuđivati“ (Konig i Zedler, 2001). Pedagoška praksa koja polazi od prednosti konstruktivističkog pristupa u procesu učenja naglašava učenje kao istraživački akt u kojemu dijete uči istraživanjem u interakciji s odraslima, drugom djecom i materijalima; u kojem su djeca tjelesno i mentalno aktivna u konkretnim aktivnostima, a koje su bitne za njihovo životno iskustvo. Interakcija djeteta s prirodom uvodi ga u slijed nadovezivanja prirode, njenih potreba, zaštite u interakciji djeteta s emocijama, što svakako pridonosi razvoju svijesti o ekološkoj edukaciji.

Ideja o suradničkom učenju (kooperativno učenje; su-konstrukcija znanja) nije nova, ali je u današnje vrijeme ponovno aktualna. „Suvremeno shvaćanje učenja djece predškolske dobi sve više ističe važnost suradnje u učenju - izgrađivanje znanja u socijalnoj interakciji u kojoj se proces učenja odvija kroz diskusiju, raspravu, suradnju i dogo- 
varanje vršnjaka" (Cvjetićanin i Sučević, 2011). U velikom opusu svojih istraživanja Bruner (2000) se posvetio i istraživanju kooperativnog učenja. On je zastupao ideju da su stjecanje znanja i komunikacija s vršnjacima po svojoj naravi krajnje međuzavisni i neodvojivi. Ekološka svijest slijedi iz interakcije djeteta $s$ prirodom, djeteta $s$ djetetom ili djeteta s odraslim. Shvaćanje biti i zaštite okoliša, po Bruneru, proizlazi iz svijesti o prirodi i okolišu uopće.

Navodi brojnih autora ističu temeljnu značajku suradničkog učenja koje se shvaća kao oblik socijalnog učenja u kojemu dolazi do izražaja učenje putem zajedničke rasprave u skupini, diskusije, dogovaranja, pregovaranja i suradnje, što može izgraditi kod djeteta ekološku svijest (Bruner, 2000; Konig i Zedler, 2001; Cvjetičanin i Sučević, 2011; Janković, 2016). Razmjena ideja s drugom djecom može pomoći djetetu u preispitivanju vlastite ideje. Ekološku svijest dijete mora ugraditi u svoj misleni plan. Kada dijete radnju koju treba misleno usvojiti može govorom točno očitovati, počinje proces njezinog prenošenja na misleni plan. Dubina shvaćanja ekološke problematike zahtjeva mislenu operacionalizaciju djeteta predškolske dobi.

Bruner (2000) drži da se djetetova želja za učenjem temelji na četiri motiva, koja možemo prepoznati i kod predškolskog djeteta: na motivu radoznalosti, kompetencije, identifikacije i motivu uzajamnog djelovanja (kooperacije). Dijete je aktivno biće, a ta aktivnost rezultat je druge značajne osobine djetinjstva - radoznalosti. Razvoj ekološke svijesti i shvaćanje djeteta o važnosti očuvanja i upoznavanja procesa iz vlastitog okoliša, relacija u prirodi, odnosa između prirode i pojedinca, ima snažan pečat upravo u toj osobini dječjeg učenja i razvoja. Bruner ističe i da se moderna pedagogija sve više približava ideji da dijete treba biti svjesno vlastitih procesa mišljenja, što je vrlo važno kako za pedagoške teoretičare tako i za odgajatelje u njihovoj težnji da pomognu djeci kako bi u procesu učenja postala svjesna načina na koji o nečemu misle ili to saznaju.

Seefeldt i Barbour (1994) ističu i sposobnost predškolskog djeteta za metakogniciju, koja označava sposobnost spoznaje vlastitih kognitivnih procesa, sposobnost samorefleksije i samovrednovanja.

S točke razvojne psihologije Levkov (1985) ekološkom odgoju i obrazovanju pristupa na specifičan način, ističući da u ekološkom proučavanju dinamičkih reakcija djece u danom ekosustavu značajno mjesto zauzima i ekološka okolina dječjeg vrtića, koju odgajatelj može strukturirati i oplemenjivati. Raznolikost ekološke okoline koja je sukladna opsegu dječjih mogućnosti u percepciji, kogniciji i ponašanju osigurava da obrazovanje bude primarno sredstvo promjene društva, usmjereno na trajnu održivost. Rad na ekološkom odgoju djece predškolske dobi omogućuje:

- viziju obrazovanja kao cjelovitog i interdisciplinarnog pristupa razvoju znanja i vještina potrebnih za trajno održivu budućnost, kao i za promjene u vrijednostima, ponašanju i životnim stilovima;

- pravo i odgovornost svakog pojedinca da na lokalnoj razini odlučuje i postupa na kulturno primjeren i relevantan način kako bi se riješili problemi koji ugrožavaju zajedničku budućnost. 


\section{DIDAKTIČKO-METODIČKI PRISTUP EKOLOŠKOM ODGOJU I OBRAZOVANJU U DJEČJEM VRTIĆU}

Opredjeljenje praktičara u odabiru pedagoško-psiholoških i metodičkih pristupa ekološkom odgoju i obrazovanju predškolske djece podrazumijeva potrebu stvaranja uvjeta koji će pomoći djetetu u sređivanju znanja i iskustva, prosudbi i njihovoj aktivnoj uporabi u svakodnevnom životu. Jedino u prirodnim, svakodnevnim situacijama, sadržaji u vezi s ekologijom imat će smisla za dijete i pomoći će mu u shvaćanju značenja prirodnih procesa i promjena. Kako bi predškolska ustanova postala nositelj ideja trajno održivog razvitka i bila u prigodi kod djece razviti kompetencije potrebne za ostvarivanje promjena nužno je poznavanje i uvažavanje određenih metodičkih puteva, koji će pomoći uspješnom ostvarivanju razvojnih ciljeva i zadataka u području spoznajnog razvitka i poznavanja sadržaja samih ekoloških pojmova.

Kompleksnost djelovanja predškolske ustanove kao odgojno-obrazovnog-ekološkog središta očituje se u smislu stupnja ispunjenosti sljedećih zahtjeva:

- truda da se u odgojno-obrazovnom radu odgajatelja pojedine teme kreativno razrade, u smjeru njihove praktične primjene;

- utvrđenih mogućnosti organiziranja odgojno-obrazovnog procesa u prirodi i u izvornom eko-okružju;

- identifikacije problema u lokalnoj sredini, koji bi omogućili djeci sudjelovanje u njihovom rješavanju;

- razvijanje sustavne sheme mišljenja, koja bi omogućila djeci traženje i uočavanje veze među pojedinim pojmovima, pojedinačno i u širem kontekstu;

- definiranog plana akcije i primjene okolišne politike, usmjerene na gospodarenje otpadom, uštedu energije, brigu o okolišu, potporu zdravom životnom stilu, suradnji s roditeljima i lokalnom zajednicom;

- iniciranih promjena na lokalnoj razini i aktivnostima usmjerenim na postizanje održivog razvoja i načina života članova zajednice kojima u konkretnoj lokalnoj zajednici pripadaju i djeca određenog vrtića.

Odlučujuća uloga odgajatelja je na neizravan način, metodički pravilnim smjerom poučavati djecu i pomoći im u stjecanju uvida u proces ekološkog odgoja, odnosno ekološko saznanje i razvoj ekološke svijesti. U osnovici metodičkog pristupa razvitku ekološke svijesti i razvitku pojmova u svezi ekološke problematike u predškolskoj dobi, osim potrebe poznavanja kognitivnog razvitka i značajki učenja predškolske djece, nužno je poznati i izabrati metodički put koji će pomoći uspješnom ostvarivanju razvojnih ciljeva i zadataka u području spoznajnog razvitka i upoznavanju sadržaja samih ekoloških pojmova.

Autori usmjereni suvremenim pogledima na predškolsku pedagogiju i dječju psihologiju ističu važnost uvažavanja životnog iskustva djeteta, što istodobno tvori jedno od važnih metodičkih načela. Pod tim se podrazumijeva potreba da se u izboru sadržaja odgojitelj rukovodi situacijama i događajima iz svakodnevnog života, točnije, da sadržaji o prirodi, od značaja za ekološki odgoj, budu povezani s iskustvom djeteta. Takvo upoznavanje 
svijeta, okoliša i prirodnih pojava je interesantnije, ali i logičnije, u smislu povezivanja stvari i procesa. Kami (1971) ističe da svakodnevno okružje može mnogo toga učiniti na neizravan način.

Poznavajući značajke ekološke tematike i posebice razumijevanje prirodnih zakona i pojmova iz okoliša djeteta, nameće se važnost primjene načela postupnosti. Ekološke pojave i prirodni procesi moraju se djeci predočavati postupno, tako da svaki prethodni pojam stoji u osnovici oblikovanja sljedećeg i uvjet je daljnjeg razumijevanja i korištenja u aktivnostima, igrama i komunikaciji predškolskog djeteta, kako bi dijete razvilo ekološku svijest. Postupnost podrazumijeva i uvažavanje razvojnih sposobnosti djece, što znači potpuno poznavanje metodičkog oblikovanja i metodičkih smjernica odgajatelja. Filozofija programa orijentiranog na dijete temelji se na dvama bitnim načelima: a) dijete izgraduje svoje znanje temeljem iskustava i interakcija sa svijetom koji ga okružuje i b) odgajatelj najbolje promiče dječji razvoj ukoliko temelji odgojnu akciju na dječjoj zainteresiranosti, potrebama i sposobnostima (Hansen i sur., 2001). Jedna od metodičkih preporuka u radu odgajatelja na razvoju ekološke svijesti i akcije predškolskog djeteta jest usmjerenost na planiranje putem projekata, pri čemu je odgajatelj kao refleksivni praktičar usmjeren na stalno promišljanje i postavljanje sljedećih pitanja:

- Što podrazumijevamo pod pojmom „održiv razvoj“?

- Što radimo kako bismo sačuvali kvalitetu života?

- Jesmo li spremni dragovoljno prihvatiti skromnost kao način života?

- Jesmo li dovoljno fleksibilni kako bismo se mogli prilagoditi novim životnim uvjetima?

- Koliko osobno pridonosimo očuvanju svog okoliša?

Definiranje ciljeva projekta u radu na razvoju ekološke svijesti prvi je korak u osmišljavanju ekološkog programa (kurikula) jedne predškolske ustanove. To bi se, najprije, odnosilo na sljedeće:

- razvoj zainteresiranosti i stjecanje prvih znanja potrebnih za oblikovanje ekološkog načina mišljenja i djelovanja;

- razvoj svijesti o potrebi zaštite okoliša;

- razvoj i njegovanje ljubavi prema prirodi i svemu živom;

- izgrađivanje pojmova o uzajamnoj povezanosti, ovisnosti i uzročnosti u prirodi;

- shvaćanje problema ugroženosti okoliša i njegovanje zaštitničkog odnosa prema prirodi i zaštitničkog, humanog odnosa prema živim bićima;

- promatranje, eksperimentiranje i izgrađivanje sposobnosti praktičnog djelovanja na području zaštite, obnavljanja i unapređivanja okoliša;

- iniciranje želje za uključivanjem u konkretne akcije;

- poticaj kreativnosti i osobne inicijative kod djece;

- izgrađivanje stava kod djece za izbjegavanja korištenja predmeta za jednokratnu uporabu;

- uvjeravanje djece o nužnosti zaštite okoliša i štednje u eksploatiranju životnih resursa; 
- skupljanje sekundarnih sirovina;

- navikavanje djece na život u suglasju s prirodom;

- uključivanje uže i šire obitelji i članova lokalne zajednice (Šain i sur., 2001).

Osmišljavanje programa aktivnosti odgajatelja i djece drugi je korak u osmišljavanju ekološkog programa u predškolskoj ustanovi, koncipiranog kao otvorenog kurikula u koji odgajatelj prema vlastitoj kreativnosti, uvjetima sredine, dječjoj dobi i vlastitom znanju, unosi nove igre i aktivnosti i vodi projekt sukladno postavljenim ciljevima. Utvrđivanje početnog stanja podrazumijeva ispitivanje postojeće razine znanja djece o ekologiji, okolišu, potrebi njezinog očuvanja i zaštite i svijesti o stanju našeg planeta. Poslije utvrđivanja inicijalnog stanja odgajatelj sastavlja plan koji obuhvaća sljedeće aktivnosti: ${ }^{1}$

- snimanje početnog stanja;

- uređenje eko kutka;

- izrada zidnih novina;

- edukacija djece i odgajatelja;

- ekološke radionice i aktivnosti s djecom;

- ekološke radionice s roditeljima;

- ekološke aktivnosti u suradnji s lokalnom zajednicom;

- ozelenjavanje dvorišta;

- organiziranje skupljanja sekundarnih sirovina;

- postavljanje spremnika za reciklažu papirne, plastične i limene ambalaže;

- osiguravanje prostora za kompostiranje;

- uređenje dvorišnog prostora;

- recikliranje papira;

- organiziranje likovnog natječaja i izložbe dječjih likovnih radova na temu „Zaštita okoliša";

- eko kviz;

- uključivanje roditelja u aktivnosti;

- uključivanje lokalne zajednice (Miličić-Trebaticki, 2011).

Predškolska ustanova na razini egzosustava svojim angažiranjem u relacijama partnerstva sa širom lokalnom zajednicom može napraviti mnogo na poboljšanju kapaciteta vrtića u radu s roditeljima i djecom na razvitku predškolske ustanove kao ekološke jedinice. Uspostavljanje veza potpore $s$ vanjskim okružjem, a posebice bogaćenje interakcije roditelja i vanjske sredine, jedna je od uloga predškolske ustanove na razini egzosustava. Predstavljajući modul za razvijanje partnerstva među roditeljima, vrtićima i lokalnom zajednicom predškolska ustanova iniciranjem i provedbom lokalnih, ekološko-obrazovnih programa dobiva novi status u lokalnoj sredini. Pripremajući roditelje za preuzimanje nove inicijative u vrtićima, omogućuje roditeljima, kao potencijalnim partnerima i suradnicima, okupljanje oko vrtića kao faktora ukupnog razvitka.

1 Sadržaj projekta „Za čistije i zelenije škole u Vojvodini“ predstavljen na stručnom skupu Metodički dani 2011. na VŠSS za obrazovanje odgojitelja u Kikindi, u obliku sažetka autorice Danijele Miličić-Trebaticki. 
Uključivanje roditelja u ekološki program rada ustanove bitan je element ekološke akcije i djelovanja odgajatelja na razini mezosustava pri čemu se mogu organizirati sljedeće zajedničke aktivnosti roditelja, djece i odgajatelja:

- edukacija roditelja (na roditeljskom sastanku prezentiranje projekta i naglašavanje potrebe njihovog sudjelovanja skupa s djecom);

- uredivanje dvorišta vrtića (velika radna akcija pod sloganom „Očistimo dvorišste našeg vrtića");

- kreativne radionice (zajednička druženja tijekom kojih djeca s roditeljima i odgajateljima kreiraju raznovrsne predmeta i eko igračke);

- maketa sela / grada (izrada makete onečišćenog i čistog sela / grada od ambalažnih i drugih materijala);

- osigurajmo pticama dom (izrada drvenih kućica i hranilica, od plastičnih flaša, za ptice koje se zatim postavljaju u dvorište vrtića) (Miličić-Trebaticki, 2011).

Projekti planirani na razini predškolske ustanove jasno definiraju i sadržaje aktivnosti djece. Temeljna funkcija projekta je predstavljanje polazne točke za odgoj i obrazovanje djece kojim će se kod njih razvijati sposobnost doživljavanja i upoznavanja prirode, uočavanja njezinih zakonitosti i ljepote, uz shvaćanje da od naše uloge u očuvanju zavisi i opstanak svega živog na našem planetu, pa i samog ljudskog roda. Aktivnosti ekologije proširuju se na probleme stvorene u odnosima među ljudskim društvom i prirodom, a njezin temeljni smisao je naučiti se ponašanju u prirodi i u suglasju s njom. Stvaranje ekološke veze djece s prirodom i sagledavanje biti interaktivnog odnosa je moguće realizirati kroz različite sadržaje kao što su:

edukacija djece (praktično i očitim sredstvima, uz ekološke publikacije priručnike, stručnu literaturu, brošure, edukacijske emisije);

Nova godina sa živim božićnim drvcem (skupljanjem sredstava, dobrovoljnim ubacivanjem novčića u kutiju, djece i odgajatelja, osiguravaju se sredstva za kupnju božićnog drvca, koje se kiti ukrasima napravljenim od prirodnih materijala, sadnja božićnog drvca u dvorištu vrtića);

- hranimo ptice tijekom zime;

- kompostiranje (drvene gajbice, organsko gnojivo - sve koje je nastalo od nekada živih biljaka i životinja, ostatci voća i povrća, ostatci biljaka iz vrta, svježe lišće, pokošena trava, talog od kave, filtri od čaja, perje, sijeno, suho lišće, isjeckan papir, grančice, ljuska od jajeta, stara zemlja);

- skupljanje sekundarnih sirovina (osiguravanje spremnika za određeni otpad)

- recikliranje papira (na recikliranom papiru pravljenje najljepših crteža);

- sijanje i sadnja cvijeća i povrća, njegovanje biljaka;

- eko zidne novine (sadržaj su dječji likovni radovi i tekstovi u svezi očuvanja životnog okoliša);

- likovno stvaralaštvo na temu očuvanja životnog okoliša;

- $\quad r a d$ s prirodnim materijalima (korištenje prirodnih materijala za izradu eko igrački s roditeljima, izrada kreativnih mozaika i kolaža);

- ekološka priredba (kao vid promocije aktivnosti djece, odgajatelja i roditelja); 
- šetnja po okolini;

- ozelenjavanje dvorišta;

- uredenje eko kutka;

- skupljanje biljaka;

- $\quad$ eko kviz (kao evaluacija svega naučenog i obrađenog);

- eksperimentiranje (kruženje vode u prirodi - promatranje što se događa s vodom iz posude kada je zagrijavamo, ovisnost biljaka o temperaturi, vodi i svjetlosti - što će se dogoditi s biljkama koje imaju ili nemaju nužne uvjete za život, što se događa s papirnatim otpadom, što s čvrstim, a što s organskim) i dr. (Miličić-Trebaticki, 2011).

Odgajatelj u radu treba poći od temeljnog cilja ekološkog odgoja i obrazovanja, a to je, u krajnjem ishodu: razvoj ekološki pismenog pojedinca koji je spreman donositi ekološke odluke koje su podjednako primjerene kako kvaliteti života čovjeka tako i kvaliteti njegovog životnog okružja.

\section{ZAKLJUČAK}

Ekološki odgoj i obrazovanje javljaju se kao nužni faktori društvenih procesa, a očituju se u djelovanju na razvoj pojedinca u cilju oblikovanja i osnaživanja ekološke svijesti i ekološke kulture, kao i u cilju usvajanja znanja iz područja ekoloških problema i potreba, a sukladno afirmiranim ekološkim vrijednostima. Oblikovanjem ponašanja i osobnosti djeteta očekuje se da će ponašanje i način života ekološki educirane osobe biti u funkciji održivog razvitka i održivog društva.

Porast potreba u suvremenom društvu za ekološkim ponašanjem svakog čovjeka potječe iz velikog broja negativnih posljedica nastalih ubrzanom degradacijom okoliša i nekontroliranom eksploatacijom prirodnih bogatstava. Zbog toga samo mentalno zdrava i ekološki odgojena osoba može pridonijeti zaustavljanju trenda uništavanja životnog prostora. Za razvitak socijalne ekologije, prema Cifriću (1989), najvažnije je uspostavljanje ravnoteže na relaciji - prirodni ambijent i čovjekovo djelovanje. Težnje razvitku ekološke kulture i ekološke svijesti djece s ciljem zaštite okoliša, provode se kroz različite sadržaje i mogućnosti, a što pruža ili omogućuje najviše ekološko educiranje.

Ekološka edukacija otvara mnoge mogućnosti i načine za razvitak i usavršavanje ekološkog pogleda djeteta na svijet. Težnja svake predškolske ustanove u planiranju i organiziranju ekološke aktivnosti i proširivanju vlastite ekološke djelatnosti nesumnjivo je značajan pokazatelj održivog razvitka, kao i smjernica za opstanak populacije. Tim prije što predškolski kurikul, pored inog, obuhvaća i dio sadržaja iz ekološke pedagogije i ekološke psihologije, a što, istodobno, ukazuje i na opredjeljenje ne samo za predškolski ekološki odgoj, već i za proces daljnjeg kontinuiranog oblikovanja ekološke svijesti kao integralnog i sveprihvaćenog dijela u sustavu individualnih i svedruštvenih vrijednosti. 


\section{LITERATURA}

Bronfenbrener, J. (1997). Ekologija ljudskog razvoja. Beograd: Zavod za udžbenike i nastavna sredstva.

Bruner, J. (2000). Kultura obrazovanja. Zagreb: Educa.

Cifrić, I. (1989). Socijalna ekologija. Zagreb: Globus.

Cifrić, I. (2012). Leksikon socijalne ekologije. Zagreb: Školska knjiga.

Cohen, J., Onunaku, N., Clothier, S. i Poppe, J. (2005). Helping Young Children Succeed: Strategies to Promote Early Childhood Social and Emotional Development. Washington, D.C.: National Conference of State Legislatures and Zero to Three. URL: https://www.zerotothree.org/document/82 (17.10.2016.)

Cvjetićanin, S. i Sučević, V. (2011). Teorijski okvir razvoja pojmova o naravi djece u predškolskoj ustanovi. Pedagogija, 3: 373-381.

Ellis, A. K. (2004). Exemplars of Curriculum Theory. New York: Routledge.

Hägglund, S. i Pramling Samuelsson, I. (2009). Early childhood education and learning for sustainable development and citizenship. International Journal of Early Childhood, 41(2): 49-63.

Hansen, A. K., Kaufmann, K. R. i Walsh, K.B. (2001). Kreiranje odgojno-obrazovnog procesa u kojem dijete ima središnju ulogu. Beograd: Centar za interaktivnu pedagogiju.

Janković, A. (2015). Suvremeni modeli očite nastave u području poznavanja prirode i društva. Novi Sad: Gradska biblioteka.

Janković, A. (2016). Evolucija pedagoških shvaćanja o očitoj nastavi - Od tradicionalnih shvaćanja do suvremenih teorija učenja i nastave. Učenje i nastava, 1: 11-30.

Johansson, E. (2009). The preschool child of today - The world-citizen of tomorrow? International Journal of Early Childhood, 41(2): 75-95.

Kamenov, E. (1999). Predškolska pedagogija. Beograd: Zavod za udžbenike i nastavna sredstva.

Kami, C. (1971). Skica programa za predškolsko obrazovanje izrađena na osnovu Pijažeove teorije, Predškolsko dete, 4: 416-431. Beograd: Savez pedagoških društava Jugoslavije.

Konig, E. i Zedler, P. (2001). Teorije znanosti o odgoju: uvod u osnove, metode i praktičnu primjenu. Zagreb: Educa.

Klemenović, J. (2009). Suvremeni predškolski programi. Novi Sad: Savez pedagoških društava Vojvodine.

Klemenović, J. i Marić Jurišin, S. (2012). „Ozelenjavanje” kurikuluma u sistemu obrazovanja i vaspitanja Republike Srbije. Zbornik radova s 2. međunarodne konferencijee Sodobni pristopi poucevanja prihajajocih generacijssa, str. 507-515. Ljubljana: EDUvision, 6.-7. prosinca 2012.

Lepičnik-Vodopivec, J. (2000). Stavovi odgajatelja o ekološkom odgoju djece u vrtiću. U: Uzelac, V. (ur.) Ekologija: korak bliže djetetu. Zbornik radova stručno znanstvenog skupa. (str. 71-76). Rijeka: Dječji vrtić Rijeka - Adamić.

Levkov, Lj. (1985). Ekološka dječja psihologija, Beograd: ZZUINS. 
Marendić, Z. (2009). Teorijski okvir razvoja matematičkih pojmova u dječjem vrtiću. Metodika, 10(18): 129-141.

Miličić-Trebaticki, D. (2011). Da nam čistije i zelenije bude - ekološke aktivnosti. Zbornik VŠSSOV, 4(2): 133-142.

Sakač, M., Cvetićanin, S. i Sučević, V. (2012). Mogućnost organiziranja odgojno-obrazovnog procesa u cilju zaštite okoliša. Socijalna ekologija, 21(1): 89-98.

Sakač, M., Marić, M. i Pantić, J. (2013). Odgajatelj u kontekstu djelovanja na socio-emocionalni i tjelesni razvitak predškolskog djeteta. Zbornik učiteljskog fakulteta u Užicu, 15: 305-312.

Seefeldt, C. i Barbour, N. (1994). Early childhood education: An introduction. New York: Merrill.

Sučević, V., Sakač, M. i Bulatović, A. (2013). Kurikul u funkciji kvalitetnog osnovnog obrazovanja-otvaranje prostora za autonomiju škola. Metodički obzori, 8(17): 15-28.

Šain, M., Topić, S., Đaković, N., Božić, D. i Galić, B. (2001). Kako pripremamo dijete za polazak u školu. Banja Luka: Centar za predškolski odgoj i obrazovanje.

Veresov, N. N. (2002). Naš dom je Zemlja. Kreativni odgoj, 10: 16-22. 


\title{
DIDACTIC AND METHODICAL APPROACH TO THE DEVELOPMENT OF ENVIRONMENTAL CONSCIOUSNESS AMONG CHILDREN WITHIN THE PREPARATORY PRE-SCHOOL CURRICULUM
}

\begin{abstract}
Vlasta Lipovac, Marija D. Sakač, Aleksandar Janković and Jelena Raičević
Abstract

All educators are faced with the challenge and task to help develop institutional educational system, on the one hand, and everyday pedagogy practices, on the other. It is also necessary to develop such curricula that promote modern tendencies in education in general, as well as, more specifically, in the development of environmental consciousness and desirable lifestyle of young people. Therefore, with regards to the existing institutional pre-school education, it is of particular importance to find suitable ways to include the so-called ecological content in the curriculum, so that it would be most effective in developing environmental consciousness and love toward nature among children during this most sensitive age. This paper, therefore, first examines some of the most important characteristics of pre-school children's cognitive development. Furthermore, we look at the most suitable content, strategies and didactic and methodical approaches for a functionally acceptable curriculum, with regards to modern environmental education of pre-school children. Alongside the proposed draft of the most acceptable curricular content, we offer concrete didactic and methodical suggestions for educators. These are mostly related to the necessity to practically implement the part of the curriculum related to environmental education, which would be based on children's experience of their immediate surroundings or, more specifically, to direct observation and experience, as well as mental reflection on things directly or indirectly perceived and experienced.
\end{abstract}

Key words: environmental education, curriculum, pre-school children, cognitive development

\section{DIDAKTISCH-METHODISCHER ANSATZ ZUR ENTWICKLUNG DES UMWELTBEWUSSTSEINS BEI KINDERN IM CURRICULUM FÜR DIE VORSCHULERZIEHUNG}

\author{
Vlasta Lipovac, Marija D. Sakač, Aleksandar Janković und Jelena Raičević
}

\section{Zusammenfassung}

Eine besondere Herausforderung und Aufgabe aller, deren Beruf Erziehungs- und Bildungsarbeit ist, ist vor allem die Entwicklung des institutionellen Bildungs- und Erziehungssystems, sowie der alltäglichen pädagogischen Arbeit. Es ist nötig, Lehrpläne zu konzipieren, die zeitgenössische Tendenzen unterstützen würden, sowohl bei der Erziehung und Bildung, als auch bei der Entwicklung des Umweltbewusstseins und eines erwünschten Lebensstils der Jugendlichen. Hinsichtlich der bestehenden institutionellen Vorschulerziehung und-bildung ist es deshalb von besonderer Bedeutung, die sogenannten ökologischen Inhalte auf die adäquate Art und Weise ins Curriculum einzusetzen, damit in diesem, für die Erziehung anfälligsten Alter möglichst effizienter Einfluss auf die Entwicklung des Umweltbewusstseins und der Liebe zur Natur ausgeübt werden kann. Dementsprechend werden in diesem Artikel erstens die wichtigsten Merkmale und der Verlauf der kognitiven Entwicklung der Kinder im Vorschulalter erörtert. Weiterhin überlegen wir, welche Inhalte, Strategien und didaktisch-methodische Verfahren am besten für ein funktionsfähiges Curriculum für zeitgenössisch begründete ökologische Erziehung und Bildung von Vorschulkindern geeignet sind. Außer den vorgeschlagenen am besten geeigneten Inhalten des Lehrplans bieten wir den praktizierenden Erziehern eine Reihe von konkreten didaktisch-methodischen Vorschlägen. Sie beziehen sich auf die praktische Realisierung der Inhalte der ökologischen Erziehung - und Bildung, vorwiegend mit Hinsicht auf Erfahrungen der Kinder in ihrer realen Umwelt, insbesondere auf ihre unmittelbaren Beobachtungen und Erlebnisse; auf die Verinnerlichung von unmittelbar und mittelbar wahrgenommenen Erlebnissen.

Schlüsselwörter: ökologische Erziehung, Curriculum, Vorschulkind, Erkenntnisentwicklung 